\section{Cytomegalovirus Colitis and Hypo-IgG After Rituximab Therapy for Rheumatoid Arthritis}

\section{To the Editor:}

Rituximab (RTX) is an anti-CD20 antibody used in patients with rheumatoid arthritis (RA) after failure of anti-tumor necrosis factor (anti-TNF) therapy. Side effects are mainly infectious, probably related to B cell lymphopenia. However, opportunistic infections are not frequent with use of RTX. We describe a case of cytomegalovirus (CMV) colitis in a patient with RA with hypo-IgG after 2 cycles of RTX.

A 66-year-old woman was followed for 18 years for RA with positive anticitrullinated protein antibodies and structural erosions. She was successively treated with methotrexate (MTX) alone for 17 years and then in combination with anti-TNF- $\alpha$ for 9 months (adalimumab, then etanercept), without success. She improved after a first course of RTX (1 gram twice) in 2007 associated with low-dose corticosteroid therapy (prednisone $10 \mathrm{mg}$ daily) and MTX $10 \mathrm{mg}$. In July 2008, the serum IgG level was found to be low: $5.25 \mathrm{~g} / \mathrm{l}$; IgG level was not monitored before starting RTX. In April 2009, because of a new episode of RA, she received a second course of RTX, with good efficacy. In September 2009, she was hospitalized because of mucous diarrhea with more than 20 stools per day, progressing for 3 months. Bacteriologic and parasitologic stool cultures and investigation for Clostridium difficile were negative. An abdominal computed tomography scan revealed a slight infiltration of the mesocolon, confirmed by the rectosigmoidoscopy, with superficial ulcerations of variable size. Blood polymerase chain reaction investigations and colonic biopsies were positive for CMV (295 copies). Serum IgG level was $2.77 \mathrm{~g} / 1$, the rate of blood B lymphocytes was zero, and the T lymphocyte count was normal $(1.964 \mathrm{~g} / \mathrm{l})$. She was treated with ganciclovir for 7 days, then valganciclovir for 15 days. She also received an infusion of $25 \mathrm{~g}$ human immunoglobulin. By the end of the first week there was almost complete disappearance of diarrhea.

We describe the first case of CMV colitis associated with hypo-IgG in a patient with RA who had received 2 cycles of RTX. One case of ulcerative colitis of noninfectious origin was described ${ }^{1}$ after 2 courses of RTX, $375 \mathrm{mg} / \mathrm{m}^{2}$, given in a patient with Graves' disease. Two other patients experienced worsening of preexisting Crohn's diseases or ulcerative colitis after $\mathrm{RTX}^{2,3}$.

Humoral immunity is necessary for defence against CMV: a recent study showed that antibodies control either primary dissemination or local viral spreading of $\mathrm{CMV}$ infection in mice ${ }^{4}$. In humans, IgG deficiency may be a risk factor for CMV infection according to some reports. A few cases of disseminated CMV infection have been described in patients with common variable immunodeficiency (CVID), mainly with a gastrointestinal presentation $^{5,6,7}$. An associated T cell defect might favor CMV infection in patients with hypo-IgG. Thus, a study reported 5 cases of post-cardiac-transplant patients who had severe CMV infections ${ }^{8}$. All of them presented with hypo-IgG $(3.23 \pm 0.18 \mathrm{~g} / \mathrm{l})$ compared to 15 other post-transplant patients without $\mathrm{CMV}$ infection $(\mathrm{IgG}=6.39 \pm 0.63 \mathrm{~g} / \mathrm{l})$. A German study ${ }^{9}$ described a 55-year-old woman treated with azathioprine and corticosteroids after resection of a thymoma, who developed CMV colitis associated with hypogammaglobulinemia $(1.8 \mathrm{~g} / \mathrm{l})$. In our patient, the $\mathrm{T}$ cell defect induced by cotreatment with steroids, even at low dose (10 mg/day), could have played a role in association with hypo-IgG in the occurrence of this severe CMV infection.

A peculiarity of recent literature about RTX is that patients in clinical trials had an increased frequency of hypo-IgG after repeated treatments with RTX ( $1.7 \%$ of patients at baseline and $4.7 \%$ after 4 cycles); there were reports of a nonsignificant increase of severe infections in these patients with hypo-IgG after repeated cycles of RTX ${ }^{10,11}$. Single case reports with dramatic post-RTX hypo-IgG have also been described: e.g., a patient treated with RTX for idiopathic thrombocytopenic purpura and autoimmune neutropenia in whom serum IgG dropped from $13 \mathrm{~g} / 1$ before treatment to $1.75 \mathrm{~g} / \mathrm{l}$ after 5 courses of RTX over 7 years, without infectious complications $^{12}$. Finally, in RA patients treated with RTX, hypo-IgG may be present before the start of RTX (i.e., up to 5\% of patients in the AutoImmunity and Rituximab registry) and this presents a risk factor for severe infections ${ }^{13}$.

Unpredictable opportunistic infections are possible in patients treated with RTX, and some of them could be favored by hypo-IgG and steroid-associated treatment. We recommend IgG monitoring before start of RTX treatment and at regular intervals afterward in patients with RA. Before starting RTX, it could be useful to look for other underlying immunodeficiency states such as CD4 deficiency.

\section{HÉLÈNE VALLET, MD; RONAN HOUITTE, MD; ALEXANDRE} AZRIA, MD; XAVIER MARIETTE, MD, PhD, Department of Rheumatology, Hôpital Bicêtre, Assistance Publique-Hôpitaux de Paris, Université Paris-Sud 11, 78 rue du Général Leclerc, 94275

Le Kremlin-Bicêtre, France. Address correspondence to Prof. Mariette; E-mail: xavier.mariette@bct.aphp.fr

\section{REFERENCES}

1. El Fassi D, Nielsen CH, Kjeldsen J, Clemmensen O, Hegedüs L. Ulcerative colitis following B lymphocyte depletion with rituximab in a patient with Graves' disease. Gut 2008;57:714-5.

2. Goetz M, Atreya R, Ghalibafian M, Galle PR, Neurath MF Exacerbation of ulcerative colitis after rituximab salvage therapy. Inflamm Bowel Dis 2007;13:1365-8.

3. Papadakis KA, Rosenbloom B, Targan SR. Anti-CD20 chimeric monoclonal antibody (rituximab) treatment of immune-mediated thrombocytopenia associated with Crohn's diesease. Gastroenterology 2003; 124:583.

4. Wirtz N, Schader SI, Holtappels R, Simon CO, Lemmermann NAW, Reddehase MJ, et al. Polyclonal cytomegalovirus-specific antibodies not only prevent virus dissemination from the portal of entry but also inhibit focal virus spread within target tissues. Med Microbiol Immunol 2008;197:151-8.

5. Medlicott SA, Coderre S, Horne G, Panaccione R. Multimodal immunosuppressant therapy in steroid-refractory common variable immunodeficiency sprue: a case report complicating cytomegalovirus infection. Int J Surg Pathol 2006;14:101-6.

6. Wada Y, Sato T, Kitajima H, Kubo M. Chronic cytomegalovirus infection that present specific clinical course - a case of a boy with common variable immunodeficiency. Nihon Rinsho Meneki Gakkai Kaishi 1995;18:247-55.

7. Daniels JA, Ledermoan HM, Maitra A, Montgomery EA. Gastrointestinal tract pathology in patients with common variable immunodeficiency (CVID): a clinicopathologic study and review. Am J Surg Pathol 2007;31:1800-12.

8. Sarmiento E, Fernandez-Yanez J, Munoz P, Palomo J, Rodriguez-Molina JJ, Bermejo J, et al. Hypogammaglobulinemia after heart transplantation: use of intravenous immunoglobulin replacement therapy in relapsing CMV disease. Int Immunopharmacol 2005;5:97-101

9. Kahraman A, Miller M, Maldonado-Lopez E, Baba HA, Treichel U, Gerken G. A 55-year-old woman with thymoma and hypogammaglobulinemia (Good syndrome), ulcerative colitis, and cytomegalovirus infection [German]. Med Klin (Munich) 2009;104:150-4.

10. Keystone E, Fleischmann R, Emery P, Furst DE, van Vollenhoven R, Bathon J, et al. Safety and efficacy of additional courses of rituximab in patients with active rheumatoid arthritis: an open-label extension analysis. Arthritis Rheum 2007;56:3896-908.

11. Van Vollenhoven RF, Emery P, Bingham CO, Keystone EC, Fleischmann R, Furst DE, et al. Longterm safety of patients receiving rituximab in rheumatoid arthritis clincial trials. J Rheumatol 2010;37:558-67.

12. Cooper N, Davies EG, Thrasher AJ. Repeated courses of rituximab 
for autoimmune cytopenias may precipitate profound

hypogammaglobulinaemia requiring replacement intravenous immunoglobulin. Br J Hematol 2009; 146:120-2.

13. Gottenberg JE, Ravaud P, Bardin T, Cacoub P, Cantagrel A, Combe B, et al; Autoimmunity and Rituximab registry and French Society of Rheumatology. Risk factors for severe infections in patients with rheumatoid arthritis treated with rituximab in the autoimmunity and rituximab registry. Arthritis Rheum 2010;62:2625-32.

J Rheumatol 2011;38:5; doi:10.3899/jrheum.100818 